\title{
Development of Electrochemical Immunosensor for Detecting Salbutamol by Competitive Immune Strategy
}

\author{
Xiao Han \\ Department of Physical Education, Zhengzhou University of Science and Technology, 450064, PR. \\ China \\ E-mail: hanxiaope88@sina.com
}

doi: $10.20964 / 2020.08 .93$

Received: 30 March 2020 / Accepted: 2 June 2020 / Published: 10 July 2020

\begin{abstract}
Salbutamol is a synthetic adrenergic receptor stimulant that is prohibited in competitive sports. In this work, an electrochemical sensor was fabricated using an immunoassay for the sensitive determination of the doping compound salbutamol. Polyamide amine-Au nanoparticle (PMA-Au) nanocomposites and horseradish oxidase-graphene antibodies (HRP-G-Abs) were used to amplify the signal. PMA-Au was used to immobilize the biomolecules in a stable manner, and graphene was used to increase the loaded amount of HRP. A competitive immune strategy was adopted for electrochemical sensor fabrication. The proposed immunosensor could linearly detect salbutamol from $0.1 \mathrm{ng} / \mathrm{mL}$ to $1 \mu \mathrm{g} / \mathrm{mL}$, with a low detection limit of $0.03 \mathrm{ng} / \mathrm{mL}$. In addition, the proposed immunosensor was successfully used to detect salbutamol in real samples.
\end{abstract}

Keywords: Immunosensor; Electrochemistry; Doping; Salbutamol; Graphene

\section{FULL TEXT}

(C) 2020 The Authors. Published by ESG (www.electrochemsci.org). This article is an open access article distributed under the terms and conditions of the Creative Commons Attribution license (http://creativecommons.org/licenses/by/4.0/). 